Anadolu Üniversitesi Bilim ve Teknoloji Dergisi A- Uygulamalı Bilimler ve Mühendislik Anadolu University Journal of Science and Technology A- Applied Sciences and Engineering

2016 - Volume: 17 Number: 1

Page: 221 - 231

DOI : $10.18038 /$ btda. 87862

Received: 03 March 2016

Revised: 11 April 2016 Accepted: 25 April 2016

\title{
INVESTIGATION OF THE STABILIZATION OF CAMPTOTHECIN ANTICANCER DRUG VIA PSA-PEG POLYMERIC PARTICLES
}

\author{
Dilay KIZIŞAR ${ }^{1}$, N. Tuna SUBAŞI ${ }^{1}$, Serap ERÖKSÜZ ${ }^{1}$, \\ Ayhan S. DEMIIR ${ }^{1}$, Olcay MERT ${ }^{1,2, *}$ \\ ${ }^{1}$ Department of Chemistry, Middle East Technical University, 06531, Ankara, Turkey \\ ${ }^{2}$ Department of Chemistry, Kocaeli University, 41380, Kocaeli, Turkey
}

\begin{abstract}
Syntheses of biodegradable PSA:PEG copolymers for the formation of nano and micro carriers were performed. Camptothecin (CPT) was selected as an anti-cancer drug. CPT can easily hydrolyze at physiological conditions (pH=7.4). This causes the loss of its activity, and it turns into inactive toxic carboxylate form from active lactone state. To keep anti cancer drug in the lactone form, it was efficiently loaded into PSA:PEG nanoparticles and microparticles, and the stability of CPT in the carriers was fully examined with HPLC. It was found that the drug was highly stable in active form in the prepared nano and microcarriers (>95\%). Particles were imaged with confocal, SEM, and optic microscopes.
\end{abstract}

Keywords: Camptothecin, PSA-PEG, Stability, Nanoparticles

\section{PSA-PEG POLİMERIK PARTIKKÜLLER İLE KAMPTOTESIN ANTIKKANSER ÍLACININ KARARLILIĞININ ARAŞTIRILMASI}

\begin{abstract}
ÖZET
Nano ve mikro taşıyıcı oluşumu için biyolojik olarak parçalanabilen PSA:PEG kopolimerlerinin sentezleri gerçekleştirilmiştir. Kamptotesin (CPT), antikanser ilaç olarak seçilmiştir. CPT fizyolojik koşullar altında kolay hidrolize olabilir $(\mathrm{pH}=7.4)$. Bu aktivite kaybına yol açar ve ilaç aktif lakton formundan aktif olmayan zehirli karboksilat forma dönüşür. Bu çalışmada anti kanser ilacı lakton formunda tutmak için, CPT etkili bir şekilde PSA:PEG nanopartikül ve mikropartiküllere yüklenmiştir ve taşıyıcı içindeki CPT kararlılığı detaylı bir şekilde HPLC ile incelenmiştir. Nano ve mikro taşıyıcılar içinde ilacın yüksek derecede kararlı ve aktif biçimde olduğu bulunmuştur (> \% 95). Son olarak parçacıklar konfokal, SEM ve optik mikroskoplar ile görüntülenmiştir.
\end{abstract}

Keywords: Kamptotesin, PSA-PEG, Kararlılık, Nanopartiküller

\section{INTRODUCTION}

Polyanhydrides such as poly(sebacic acid) (PSA), poly(adipic acid) (PAA) and poly(dodecanoic anhydride) have properties of biocompatibility due basically to the hydrolytic instable anhydride linkages and biodegradability through surface erosion, and they have had remarkable interest in the applications of sustained drug delivery systems [1-3]. Poly(sebacic acid)s can be synthesized by meltpolycondensation method in vacuum just after obtaining their prepolymers via refluxing sebacic acid and acetic anhydride [3,4].

Biodegradable poly(sebacic acid)s-PEG copolymers can be synthesized with melt polymerization after acetylations of sebacic acid prepolymer and PEG prepolymer are performed [5-6]. Also, the reaction

\footnotetext{
*Corresponding Author: olcay.mert@kocaeli.edu.tr
} 
of sebacoyl chloride with PEG yields a thermosensitive PEG-SA copolymer [7]. Variation in molecular weight and composition leads to change in sol-gel transition temperature. Additionally, the release of model drug, FITC-dextran, is tested from the gel over $24 \mathrm{~h}$ [7]. For the drug delivery applications, nanoparticles of PEG-PSA copolymers are tested in human cervicovaginal mucus, and they show rapid penetration through mucosal barrier [8], and PEG-PSA particles show improved efficacy of local etoposide delivery against small cell lung cancer in vivo [9].

Camptothecin (CPT), pentacyclic quinoline alkaloid, was firstly isolated from the Chinese tree camptotheca acuminata in 1966 (Figure 1) [10].

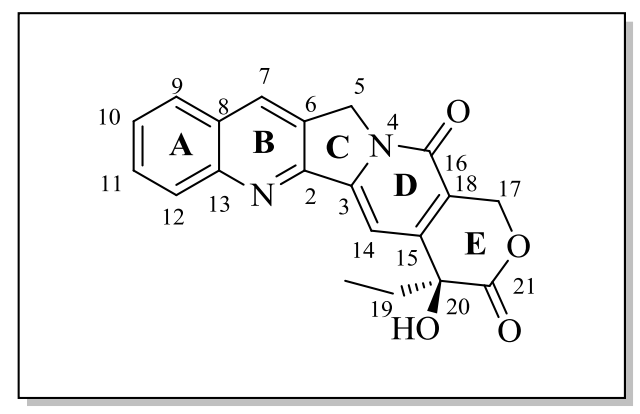

Figure 1. Structure of camptothecin

Camptothecin remarkably shows anticancer property by inhibiting DNA topoisomerase I [11]. Extraction of CPT from the intact plants, Camptotheca acuminate and Nothapodytes foetida, is the main source of CPT for pharmaceutical market. Its semi-synthetic derivatives synthesized from CPT plants are topotecan (hycamtin) and irinotecan (CPT-11) anticancer agents. These two anti-cancer drugs have been approved by FDA and have nearly US $\$ 1$ billion in annual reported worldwide sales [12]. Clinic limitation for CPT derivatives is that hydrolyzation of the lactone ring moiety of camptothecin under physiological conditions i.e. at $\mathrm{pH}=7$ or above leads to an inactive and more water-soluble carboxylate form [13-16]. The clinical results showed that biological activity of carboxylate form was weak with regard to xenograph models and unexpected side effects consisting of hemorrhagic cystitis and myelotoxicity, which led to suspension of the trials [17, 18]. CPT took more attentions just after its cellular target was discovered as DNA topoisomerase I. Thus, more watersoluble CPT derivatives such as topotecan and irinotecan were synthesized for clinical applications $[19,20]$.

Preparation, physical properties, and clinic studies of camptothecin based drug carriers were reported in literature [21-25]. Effects of polymer molecular weight, polymer concentration, and carrier solvent composition on 10-Hydroxycampthecin release profiles from microspheres were studied in detail [21]. Also, it was found that 10-Hydroxycampthecin in poly(lactide-co-glycolide) (PLGA) microspheres were highly stable during two months [21]. A nanoparticulate system having high efficacy toward tumor cells was developed with the combination of CPT, anti-Fas antibody, and PLGA [22]. Also, camptothecin was employed as an initiator for the polymerization of lactide in the presence of $(\mathrm{BDI}) \mathrm{ZnN}(\mathrm{TMS})_{2}$ catalyst. It was found that the type of metals, chelating ligands, and reaction medium conditions dramatically affected stability of the lactone ring of camptothecin [23]. DNA interactions of two commercial drugs of camptothecin family drugs, CPT-11 and topotecan were examined at physiological conditions [24]. Stabilization of active lactone ring of both drugs in between $78 \%$ and $95 \%$ in presence of duplex DNA oligonucleotides ((dG-dC) $)_{15}$ and (dA-dT) $)_{15}$ ) may draw a conclusion that the drug may have some interaction with chromosomal DNA molecules prior to the action by topoisomerase I [24]. Also, it was shown that poly(w-pentadecalactone-co-butyleneco-succinate) nanoparticles could be used as biodegradable carriers for camptothecin delivery. CPT 
was stabilized with these nanoparticles, and they displayed important cellular uptake, significant cytotoxicity towards various cell lines in vitro and high antitumor efficiency in vivo [25].

In conclusion, closed $\alpha$-hydroxy lactone ring moiety must be intact for antitumor activity because lactone ring was a crucial structural requirement for both passive diffusion of drug into cancer cells as well as desired drug interaction with the pharmacological target topoisomerase 1 [26]. We previously showed prevention of the activity loss of camptothecin family anticancer drugs with a simple efficient platform using injectable and biodegradable block copolymer PLLA-mPEG gels [27]. Here, we aimed to formulate nano and microcarriers from different type of biodegradable polymers like PSA:PEG copolymers for the stabilization of camptothecin anti cancer drug (intact lactone form) for possible systemic delivery applications (i.e. i.v.). To the best of our knowledge, the stability of camptothecin drugs via PSA:PEG nano and micro carriers was first time reported.

\section{EXPERIMENTAL}

\subsection{Materials and Methods}

Sebacic acid monomer (Aldrich) and PEG-600 homopolymer (Aldrich) were used in the synthesis of PEG:PSA copolymer. Diethyl ether (J.T. Baker), toluene (Sigma) and petroleum ether (J.T. Baker) were employed in purification steps. Trisma-base (Aldrich), $\mathrm{NaOH}$ (Aldrich) and $\mathrm{HCl}$ (Aldrich) were employed in the buffer preparations. Camptothecin was purchased from Chengdu Haojie Pharmchem in China and used as received. Triethylamine (Aldrich), acetonitrile (J.T. Baker) and acetic acid (J.T. Baker) were employed in preparation of mobile phase and filtered out with filtration system prior to use.

\subsection{Equipment}

Zeiss LSM 510 Confocal laser scanning microscope (Carl Zeiss MicroImaging) equipped with argon laser (488 nm) and LP505 emission filter was employed. Zeiss Axioskop 2 plus optic microscope with 100X magnification with Hitachi CCD camera was used for the measurements of carriers. HPLC spectra were recorded on Thermo Finnigan HPLC with fluorescence dedector. The data analysis was performed with Chromquest software program. Carboxylate and lactone forms of anti cancer drugs

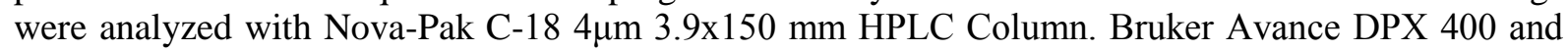
Avance III Ultrashield instruments were employed for ${ }^{1} \mathrm{H}-$ and ${ }^{13} \mathrm{C}-\mathrm{NMR}$ measurements. Samples were prepared with deuterio-chloroform $\left(\mathrm{CDCl}_{3}\right)$ in NMR tubes. Particle size and shape were also determined by QUANTA 400F FE-SEM.

\subsection{Synthesis of Sebacic Acid Prepolymer}

$10.0 \mathrm{~g}$ sebacic acid and $100 \mathrm{~mL}$ of acetic anhydride were placed into $250 \mathrm{ml}$ two necked round flask. $\mathrm{N}_{2}$ was passed through the system, and the flask was immersed into oil bath. It was refluxed at $145{ }^{\circ} \mathrm{C}$ for $15 \mathrm{~min}$ before mixture was brought into room temperature. The solvent was evaporated under reduced pressure with rotary evaporator. Recrystallization was performed with dry toluene, and then residual solvent was removed with reduced pressure over a few hours. ${ }^{1} \mathrm{H}-\mathrm{NMR}\left(\mathrm{CDCl}_{3}\right) \delta(\mathrm{ppm})$ : 2.45 (t, 4H, $\left.\mathrm{CH}_{2}\right), 2.21$ (s, 6H, $\left.\mathrm{CH}_{3}\right), 1.65$ (m, 4H, $\left.\mathrm{CH}_{2}\right), 1.33$ (m(br-s), 8H, $\mathrm{CH}_{2}$ ) [5,6].

\subsection{Synthesis of PEG Prepolymer}

$10.0 \mathrm{~g}$ PEG diacid and $200 \mathrm{~mL}$ of acetic anhydride were placed into $250 \mathrm{ml}$ two necked round flask. $\mathrm{N}_{2}$ was passed through system, and the flask was immersed into oil bath. It was refluxed at $145{ }^{\circ} \mathrm{C}$ for $30 \mathrm{~min}$ before mixture was brought into room temperature. The solvent was evaporated under reduced 
pressure. The residue was extracted with anhydrous ether and dried in vacuum. ${ }^{1} \mathrm{H}-\mathrm{NMR}\left(\mathrm{CDCl}_{3}\right) \delta$ (ppm): $4.29\left(\mathrm{~s}, \mathrm{CH}_{2}\right), 3.65\left(\mathrm{~s}, \mathrm{OCH}_{2} \mathrm{CH}_{2}\right), 2.25\left(\mathrm{~s}, \mathrm{CH}_{3}\right)[5,6]$.

\subsection{Synthesis of PEG:PSA Copolymer}

$1.0 \mathrm{~g}$ acyl- $\mathrm{PEG}_{0.6 \mathrm{k}}$ and $1.0 \mathrm{~g}$ acyl-SA prepolymer were placed into three necked $50 \mathrm{~mL}$ flask under nitrogen. Then, it was directly immersed into $185^{\circ} \mathrm{C}$ oil bath. It was mixed about 1 min before vacuum was opened. Pump pressure was $3.2 \times 10^{-1}$ mbar. It was stirred about $15 \mathrm{~min}$. Then, the vacuum channel was closed for $30 \mathrm{~s}$ to provide nitrogen gas sweep. Polymerization continued for 10-12 min more. After it was cooled down, chloroform was added into mixture followed by precipitation with 40-50 $\mathrm{mL}$ of petroleum ether. Then, the product was dried under vacuum for few hours. Amount obtained: 1.50 g. ${ }^{1} \mathrm{H}-\mathrm{NMR}\left(\mathrm{CDCl}_{3}\right): \delta(\mathrm{ppm}): 4.27\left(\mathrm{~s}, \mathrm{CH}_{2}\right), 3.65\left(\mathrm{~s}, \mathrm{OCH}_{2} \mathrm{CH}_{2}\right), 2.44\left(\mathrm{t}, 4 \mathrm{H}, \mathrm{CH}_{2}\right), 1.65(\mathrm{~m}, 4 \mathrm{H}$, $\left.\mathrm{CH}_{2}\right), 1.33$ (m(br-s), 8H, $\left.\mathrm{CH}_{2}\right)$. [5,6].

\subsection{Nanoparticle and Microparticle Formulations of PEG:PSA Copolymer}

Nanoprecipitation (Solvent Diffusion) and Single Emulsion methods were performed to formulate camptothecin loaded PEG-SA nanoparticles and microparticles, respectively.

For diffusion method, copolymer and camptothecin were dissolved in DMSO then it was added dropwisely into $40 \mathrm{ml}$ of $1 \%$ PVA aqueous phase followed by 3 hours stirring. Lastly, particles were washed with water three times using centrifuge at $10 \mathrm{k} \mathrm{rpm}$ before freeze-dried.

For single emulsion method, copolymer and CPT were dissolved in chloroform methanol mixture (4:1). $200 \mu \mathrm{l}$ water was added before probe sonication was performed. Then, emulsion was poured into $40 \mathrm{ml}$ of $1 \%$ PVA solution. Particles were washed with water three times using centrifuge at $10 \mathrm{k}$ rpm.

\subsection{HPLC Analysis}

After lyophilization, drug loaded particles were dissolved in DMSO and were diluted with about $1 \mathrm{~mL}$ of $\mathrm{pH}=7.4$ tris buffer in vial. Then, it was immediately analyzed with HPLC having C18 reverse phase column and fluorescence detector. Excitation and emission wavelengths used in HPLC analysis were 370 and $432 \mathrm{~nm}$, respectively. Also, mobile phase was 23:77 (v/v) ACN-TEAA buffer (1\%, v/v, pH: 5.5) for CPT analysis. For control experiments; $3 \mu 1$ of $10^{-3} \mathrm{M}$ CPT in DMSO was diluted with $1 \mathrm{~mL}$ of tris buffer at $\mathrm{pH}=7.4$ in vial. Then, it was immediately analyzed with HPLC equipped with fluorescence detector using wavelengths above.

\subsection{Preparation of Tris Buffer}

$606 \mathrm{mg}$ trisma-base was mixed with $250 \mathrm{ml}$ of distilled water. Then, it was stirred some time for complete dissolution. Medium of $\mathrm{pH}$ was brought into acidic, neutral and basic conditions (5.0, 7.4 or 9.9) with diluted hydrochloric acid or sodium hydroxide solutions.

\subsection{Preparation of Free CPT Stock Solution}

In order to keep the final concentration $10^{-3} \mathrm{M}, 8.7 \mathrm{mg}$ of CPT powder was fully dissolved in $25 \mathrm{ml}$ of DMSO in a graduated flask. It was covered with aluminum foil and stored at $4{ }^{\circ} \mathrm{C}$ in fridge. The solution was brought to room temperature and held about 1 hour for dissolution of DMSO prior to use in HPLC analysis. 


\subsection{Preparation of Triethylamine Acetate (TEAA) Buffer}

$10 \mathrm{ml}$ of triethyl amine was mixed with $990 \mathrm{~mL}$ of distillated water in graduated flask. $\mathrm{pH}$ of system was brought to 5.5 with glacial acetic acid. Suction filtration was performed for the removal of potential dusts, and it was degassed prior to use in HPLC.

\section{RESULTS AND DISCUSSION}

\subsection{Stability Problem of CPT Based Drugs}

One of the major shortcomings of camptothecin family is the hydrolyzation of the lactone ring moiety of the drug under physiological conditions i.e. at $\mathrm{pH} 7$ or above (Figure 2), revealing low biologic activity and high toxicity [26,27]. Thus, lactone ring was a crucial structural necessity for both passive diffusion of CPT anticancer drug into cancer cells as well as desired CPT interaction with DNA pharmacological target topoisomerase 1 .

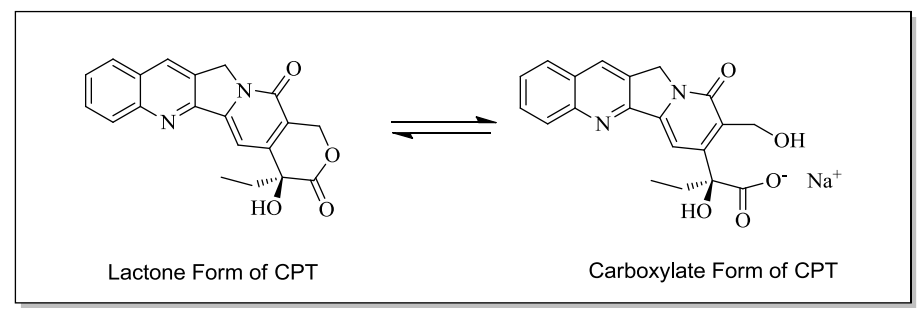

Figure 2. Camptothecin hydrolysis to water soluble sodium salt

\subsection{Preparation of Polymeric PEG:PSA Particles for the Camptothecin Anticancer Drug Delivery System}

\subsubsection{Synthesis of sebacic acid prepolymer}

As a precursor for melt polymerization of PEG:PSA, acylated prepolymer of sebacic acid is synthesized from sebacic acid in acetic anhydride at reflux temperature under nitrogen atmosphere (Figure 3) [5,6]. Characterization of prepolymer is performed with ${ }^{1} \mathrm{H}-\mathrm{NMR}$. Main chain $-\mathrm{CH}_{2}$ units have resonances in $1.33 \mathrm{ppm}, 1.65 \mathrm{ppm}$ and $2.45 \mathrm{ppm}$. Also, acetyl methyl groups at the ends give a peak at $2.21 \mathrm{ppm}$.

$$
\text { Sebacic Acid } \frac{\text { Reflux }}{\text { Acetic Anhydride }}
$$

Figure 3. The preparation of monomeric SA prepolymer

\subsubsection{Synthesis of PEG prepolymer}

As a second precursor for melt polymerization of PEG:PSA, prepolymer of acetylated PEG is prepared from PEG diacid in acetic anhydride at reflux temperature under nitrogen atmosphere (Figure 4) $[5,6]$. Characterization of prepolymer is carried out with ${ }^{1} \mathrm{H} \mathrm{NMR}$. While $\mathrm{CH}_{2}$ units have resonances in $3.65 \mathrm{ppm}$, and $4.29 \mathrm{ppm}$, acetyl methyl groups at both ends give a peak at $2.25 \mathrm{ppm}$. 


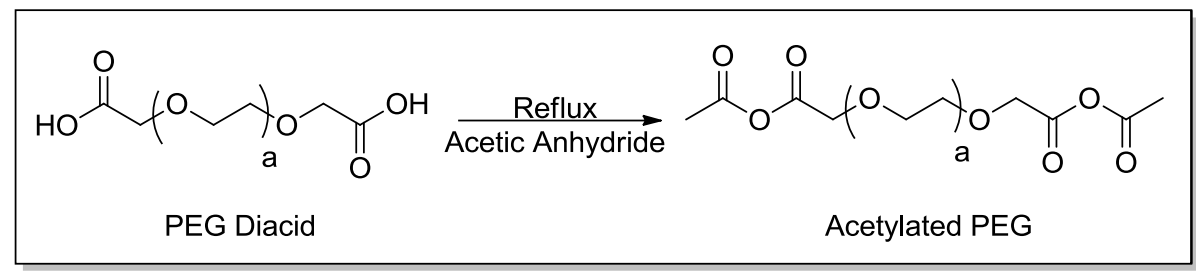

Figure 4. The preparation of acetylated PEG prepolymer

\subsubsection{Synthesis of PEG:PSA Copolymer}

Poly(ether-anhydride) is synthesized by melt polycondensation of both acetylated PEG and SA prepolymers under high vacuum conditions at high temperature (Figure 5). Characterization of PEG:PSA copolymer is performed with ${ }^{1} \mathrm{H}$ NMR. PEG components give signals at $3.65 \mathrm{ppm}$ and 4.27 ppm while SA components have resonance at $2.44 \mathrm{ppm}, 1.65 \mathrm{ppm}$ and $1.33 \mathrm{ppm}[5,6]$.

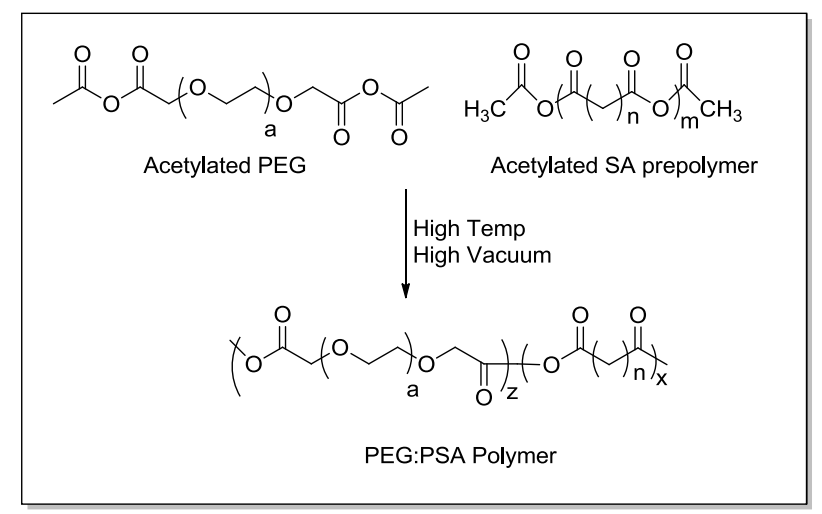

Figure 5. The preparation of PEG: PSA copolymer

\subsubsection{Nanoparticle and microparticle formulations of PEG:PSA copolymer}

Nanoprecipitation (Solvent Diffusion) and Single Emulsion methods were performed to formulate camptothecin loaded PEG-PSA nanoparticles and microparticles in $1 \%$ PVA aqueous phase. Camptothecin loaded nanoparticles were made with diffusion method. They showed the size of $360 \pm 4$ $\mathrm{nm}$ by volume as shown in Figure 6. Unimodal particle size distribution was observed. Most importantly particle size analysis proved that there was no aggregation in the formulated nanoparticles, as shown in Figure 6. On the other hand, drug loaded microparticles were formulated with single emulsion method and characterized with particle size analyzer $(14 \pm 0.6 \mu \mathrm{m}$ size by volume, data not shown). Also, particle images were recorded by Confocal, SEM and Light Microcopes, as indicated in Figure 7. Confocal microscopy was used to visualize encapsulation of fluorescent therapeutic CPT anticancer drug and distribution of the particles. Especially, fluorescence character of camptothecin drug was clearly observed in confocal image (blue light emitted from CPT). Based on SEM image, particles were observed to be spherical with quite smooth surface. The absence of free CPT aggregations was verified in SEM and light microscope images. This is another proof of the encapsulation of drug in carriers (Figure 7). 


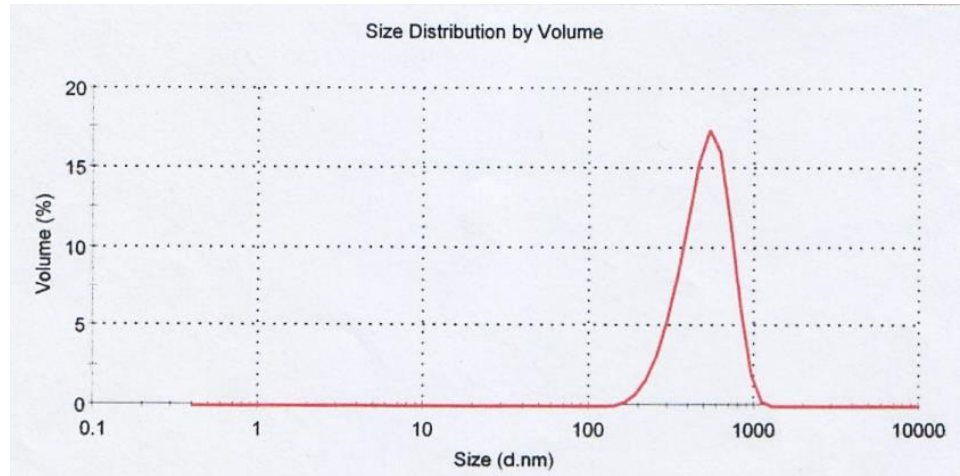

Figure 6. Size distribution report by volume for CPT loaded nanoparticles. Nanoparticle measurements were consecutively repeated three times

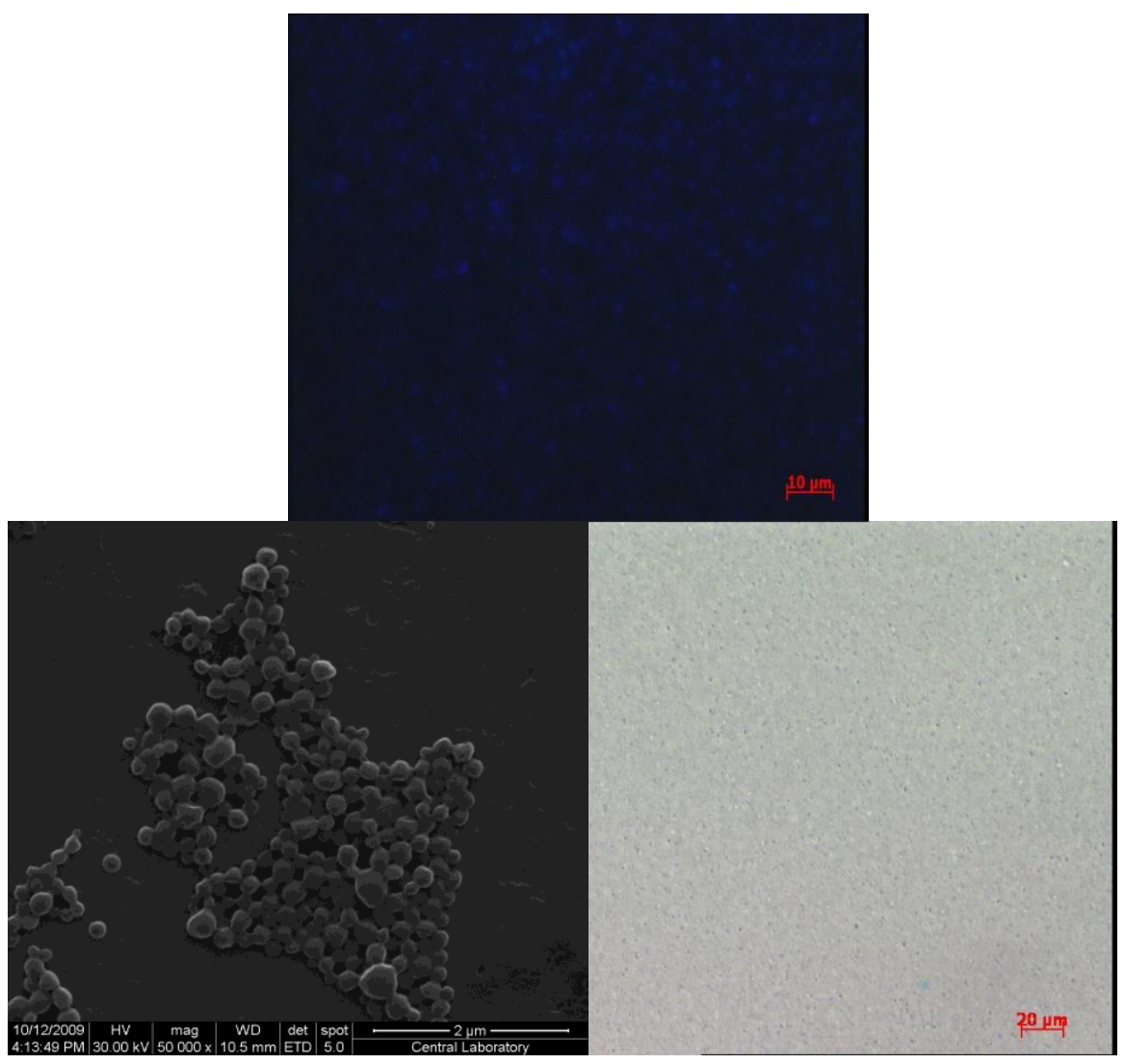

Figure 7. Particle images of confocal, SEM and light microscopes

\subsubsection{HPLC analysis}

In order to separate the lactone and carboxylate forms of free CPT anticancer drug, simple and versatile high-performance liquid chromatographic method was employed [27,28]. Triethyl amine acetate (TEAA) and acetonitrile (ACN) were the components of mobile phase system. In this method, advantages of triethyl amine are the usages for an ion pairing substance, a masking agent for underivatized silanols and essential buffer constituent for the $\mathrm{pH}$ adjustment. Thus, it makes possible 
sufficient retention and good separation for carboxylate species on column. On the other hand, Acetonitrile was selected to control lactone species of drugs.

\subsubsection{Analysis of lactone conversion of free CPT via HPLC}

Retention time of pure carboxylate and pure lactone of free CPT was determined at basic $\mathrm{pH}$ (9.9) and acidic $\mathrm{pH}$ (5.0), respectively. HPLC analysis was performed with C-18 column using ACN- TEAA buffer mobile phase. Carboxylate peak of CPT appeared at $1.51 \mathrm{~min}$ while lactone peak gave a signal at $4.21 \mathrm{~min}$ (data not shown).

When behaviors of CPT in tris buffer at $\mathrm{pH}=7.4$ were examined with time elapsed, decrease in lactone form and increase in carboxylate form were observed. Lactone to carboxylate conversion of free CPT was shown in HPLC chromatograms in Figure 8.

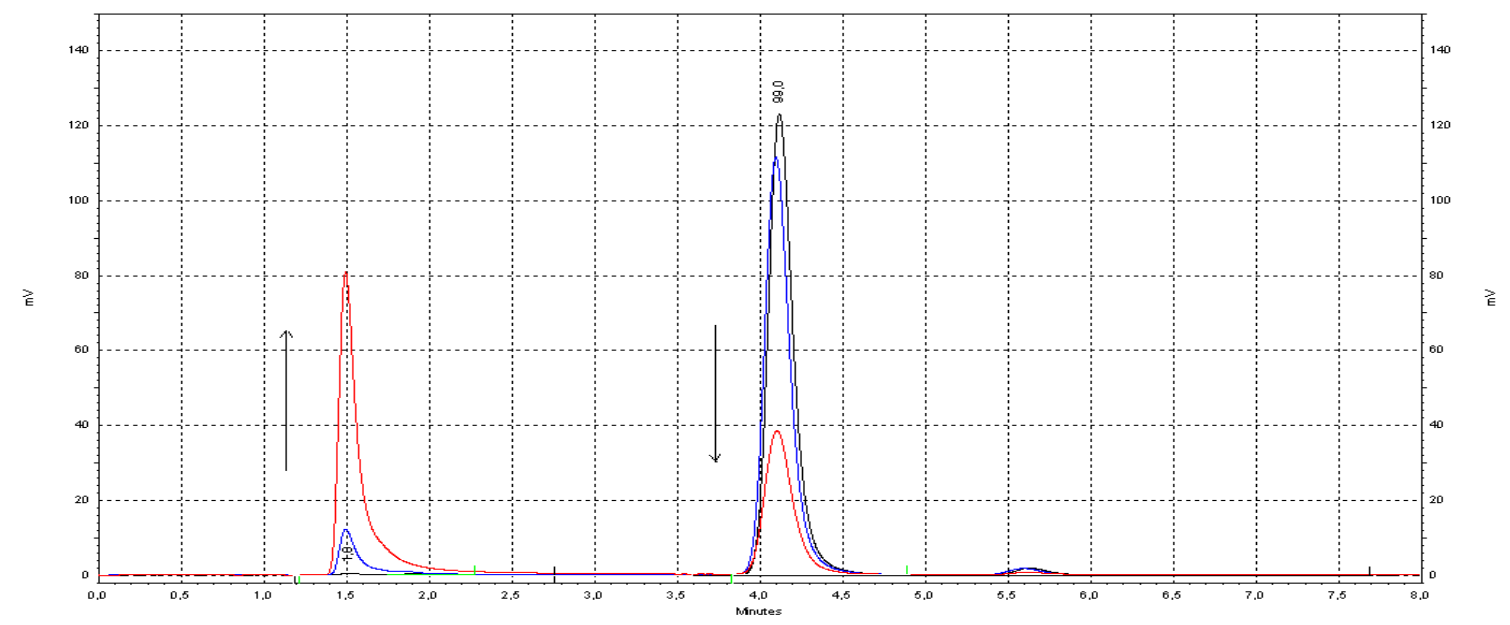

Figure 8. HPLC Chromatogram of the conversion of lactone to carboxylate of free CPT with time elapsed, respectively. All stability measurements were repeated three times.

\subsubsection{Analysis of CPT loaded particles by HPLC}

After the positions of lactone and carboxylate forms of free camptothecin are identified with high performance liquid chromatographic method, lactone and carboxylate forms of CPT in micro and nano particles were examined, and it was found that CPT is very stable in polymeric carriers. For example, in representative example of CPT loaded microparticules, CPT is in $99.2 \%$ lactone form, as shown in Figure 9. 


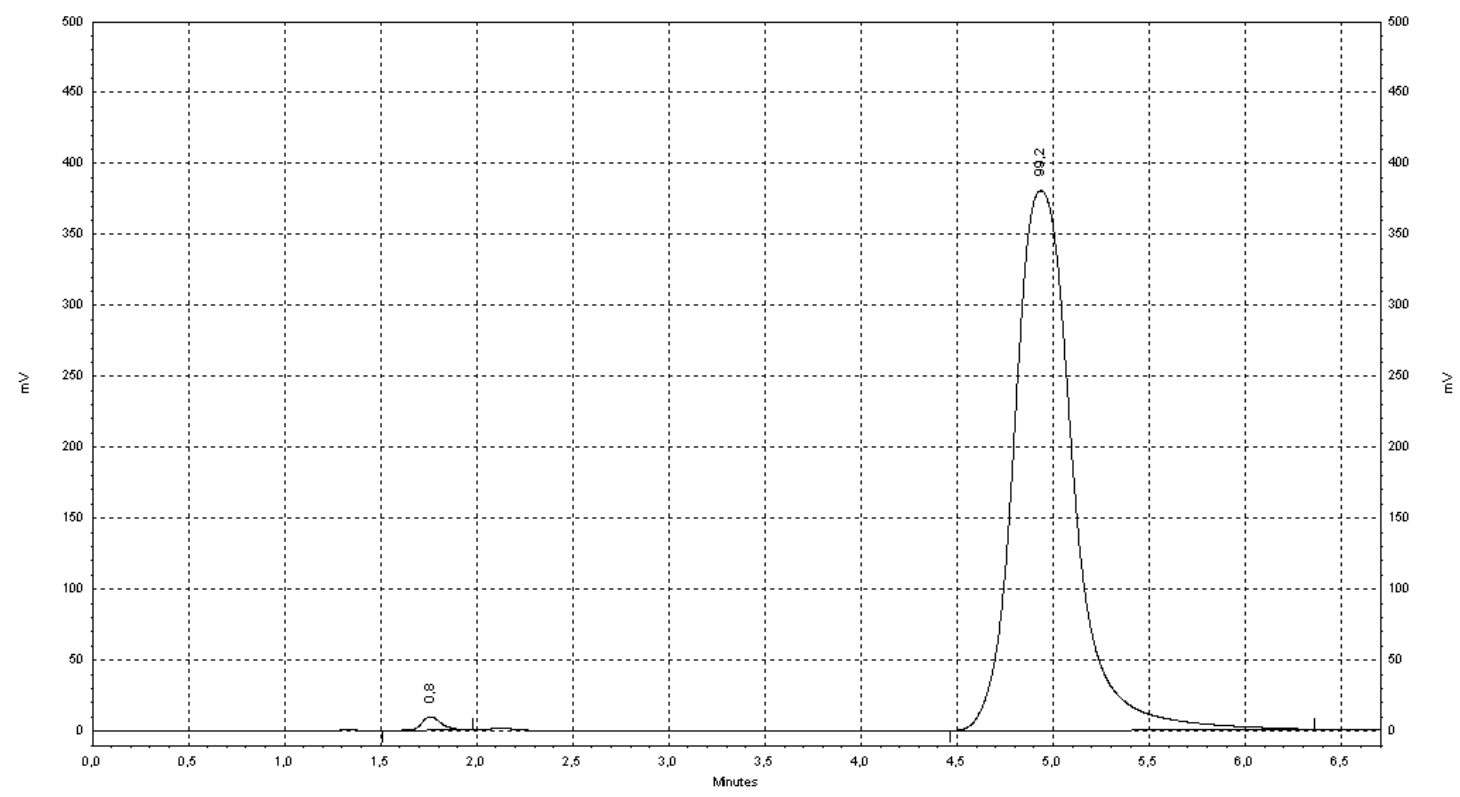

Figure 9. Representative HPLC Chromatogram of CPT loaded polymeric microparticles. All stability measurements of drug in carriers were repeated three times. Lactone percentage of drug in microparticles was $99.2 \pm 0.2$.

\section{CONCLUSION}

Camptothecin and its derivatives become more popular every day in the clinical studies due to their therapeutic effects on human cancer. One of the major shortcomings of camptothecin family is the hydrolyzation of the lactone ring moiety of the drug under physiological conditions i.e. at $\mathrm{pH} 7$ or above, revealing low biologic activity and high toxicity [26,27]. Thus, lactone ring was a crucial structural neccessity for both passive diffusion of CPT into cancer cells as well as desired CPT interaction with the pharmacological target DNA topoisomerase 1. In the present work, we developed an efficient and simple strategy for maintaining lactone moiety of camptothecin via biodegradable biocompatible PSA-PEG nano and microcarriers for a potential application in the primary malignant brain tumor or breast cancer.

\section{ACKNOWLEDGEMENTS}

The Middle East Technical University, the Turkish State Planning Organization, and OYP are gratefully acknowledged.

\section{REFERENCE}

[1] Hou S, McCauley L K, Ma P X. Synthesis and erosion properties of PEG-containing Polyanhydrides. Macromol Biosci 2007; 7: 620-628.

[2] Shuai X, Tan H. Synthesis and properties of biodegradable copolymers based on polyether oligomers and fatty diacids. J Appl Polym Sci 1997; 66: 1891-1898.

[3] Domb A J, Langer R. Polyanhydrides. I. Preparation of high molecular weight polyanhydrides. J Polym Sci A1 1987; 25: 3373-3386. 
[4] Kumara N, Langer R S, Domb A J. Polyanhydrides: an overview. Adv Drug Deliver Rev 2002; 54: 889910.

[5] Fu J, Fiegel J, Hanes J. Synthesis and characterization of PEG-based ether-anhydride terpolymers: novel polymers for controlled drug delivery. Macromolecules 2004; 37: 7174-7180.

[6] Fu J, Fiegel J, Krauland E, Hanes J, New polymeric carriers for controlled drug delivery following inhalation or injection. Biomaterials 2002; 23: 4425-4433.

[7] Lee J, Joo M K, Oh H, Sohn Y S, Jeong B. Injectable gel: poly(ethylene glycol)-sebacic acid polyester. Polymer 2006; 47: 3760-3766.

[8] Tang BC, Dawson M, Lai S K, Wang Y Y, Zeitlin P, Boyle M P, Fu J, Hanes J. Biodegradable polymer nanoparticles that rapidly penetrate the human mucus barrier. Pro Natl Acad Sci USA 2009; 106: $19268-73$.

[9] Tang B C, Fu J, Watkins D N, Hanes J, Enhanced efficacy of local etoposide delivery by poly(ether-anhydride) particles against small cell lung cancer in vivo. Biomaterials 2010; 31: 339-44.

[10] Wall M E, Wani M C, Cook C E, Palmer K H, McPhail A T, Sim G A. Plant antitumor agents. I. The isolation and structure of camptothecin, a novel alkaloidal leukemia and tumor inhibitor from camptotheca acuminata. J Am Chem Soc 1966; 88: 3888-90.

[11] Hsiang Y H, Hertzberg R, Hecht S, Liu L F. Camptothecin induces protein-linked DNA breaks via mammalian DNA topoisomerase I. J Biol Chem 1985; 260(27): 14873-14878.

[12] Oberlies N H, Kroll D J, Camptothecin and taxol: historic achievements in natural products research. J Nat Prod 2004; 67(2): 129-135.

[13] Fassberg J, Stella V J, A kinetic and mechanistic study of the hydrolysis of camptothecin and some analogues. J Pharm Sci 1992; 81: 676-684.

[14] Wani M C, Nicholas A W, Manikumar G, Wall M E. Plant antitumor agents. 25. Total synthesis and antileukemic activity of ring A substituted camptothecin analogs. structure-activity correlations. $\mathbf{J}$ Med Chem 1987; 30: 1774-1779.

[15] Wani M C, Nicholas A W, Wall M E. Plant antitumor agents. 28. Resolution of a key tricyclic synthon, 5'(RS)-1,5-dioxo-5'-hydroxy-2'H,5'H,6'H-6'-oxopyrano[3',4'-f].delta.6,8-tetrahydroindolizine: total synthesis and antitumor activity of 20(S)- and 20(R)-camptothecin. J Med Chem 1987; 30: 2317-2319.

[16] Jaxel C, Kohn K W, Wani M C, Wall M E. Pommier, Y. Structure-Activity study of the actions of camptothecin derivatives on mammalian topoisomerase I: evidence for a specific receptor site and a relation to antitumor activity. Cancer Res 1989; 49: 1465-1469.

[17] Moertel C G, Schutt A J, Reitemeier R J, Hahn R G. Phase II study of camptothecin (NSC100880) in the treatment of advanced gastrointestinal cancer. Cancer Chemoth Rep 1972; 56: 95-101.

[18] Gottlieb J A, Luce J K. Treatment of malignant melanoma with camptothecin. Cancer Chemoth Rep 1972; 56: 103-105. 
[19] Dancey J, Eisenhauer E A. Current perspectives on camptothecins in cancer treatment. $\mathrm{Br}$ J Cancer 1996; 74: 327-338.

[20] Pommier Y, Pourquier P, Fan Y, Strumberg D. Mechanism of action of eukaryotic DNA topoisomerase I and drugs targeted to the enzyme. Biochim Biophys Acta 1998; 1400: 83-106.

[21] Shenderova A, Burke T G, Schwendeman S P. Stabilization of 10-Hydroxycamptothecin in poly(lactide-co-glycolide) microsphere delivery vehicles. Pharm Res 1997; 14: 1406-1414.

[22] McCarron P A, Marouf W M, Quinn D J, Fay F, Burden R E, Olwill S A, Scott C J. Antibody targeting of camptothecin-loaded PLGA nanoparticles to tumor cells. Bioconjugate Chem 2008; 19: 1561-1569.

[23] Tong R, Cheng J. Controlled Synthesis of Camptothecin-Polylactide Conjugates and Nanoconjugates. Bioconjugate Chem 2010; 21: 111-121.

[24] Yang D, Strode J T, Spielmann H P, Wang A H-J, Burke T G. DNA Interactions of two clinical camptothecin drugs stabilize their active lactone forms. J Am Chem Soc 1998; 120: 2979-2980.

[25] Liu J, Jiang Z, Zhang S, Saltzman W M. Poly( $\omega$-pentadecalactone-co-butylene-co-succinate) nanoparticles as biodegradable carriers for camptothecin delivery. Biomaterials 2009; 30: 5707-5719.

[26] Wani M C, Ronman P E, Lindley J T, Wall M E. Plant antitumor agents. 18. synthesis and biological activity of camptothecin analogs. J Med Chem 1980; 23: 554-560.

[27] Mert O, Esendaglı G, Dogan A L, Demir A S. Injectable biodegradable polymeric system for preserving the active form and delayed-release of camptothecin anticancer drugs. RSC Adv 2012; 2: 176185.

[28] Warner D L, Burke T G. Simple and versatile high-performance liquid chromatographic method for the simultaneous quantitation of the lactone and carboxylate forms of camptothecin anticancer drugs, J Chromatogr B Biomed Sci Appl 1997; 691: 161-171. 